\title{
Economic Environmental Management Tools in the Serra Do Espinhaço Biosphere Reserve
}

\author{
Sérgio Augusto Domingues \\ Serra do Espinhaço Biosphere Reserve coordinator \\ Pontifícia Universidade Católica de Minas Gerais \\ Dom José Gaspar 500, 30535-901 Belo Horizonte, Brazil \\ Tel: 55-31-3319-4444_E-mail: sergioguto@gmail.com
}

Cláudia Santiago Karez (Corresponding author)

UNESCO Regional Bureau for Science for Latin America and the Caribbean

Luis Piera 1992, 2. Piso, 11000 Montevideo, Uruguay

Tel: 598-2413-2075Ｅ-mail: cskarez@unesco.org.uy

Isabella Virgínia Freire Biondini

Fundação João Pinheiro, Alameda das Acácias, 70

31275-150 - Belo Horizonte, MG - Brazil

Tel: 55-31-3448-9427Ｅ-mail: isabella.freire@fjp.mg.gov.br

Miguel Ângelo Andrade

Serra do Espinhaço Biosphere Reserve vice-coordinator

Pontifícia Universidade Católica de Minas Gerais

Dom Gaspar 500, 30535-901 Belo Horizonte, Brazil

Tel: 55-31-3319-4444_E-mail: miguelandrade@pucminas.br

Geraldo Wilson Fernandes

Universidade Federal de Minas Gerais, Instituto de Biociências

Av. Presidente Antonio Carlos 6627, 30161-970 Belo Horizonte, Brazil

Tel: 55-031-3409-2580 E-mail: gw.fernandes@gmail.com

$\begin{array}{lcc}\text { Received: February 2, } 2012 & \text { Accepted: March 1, } 2012 & \text { Published: April 1, } 2012 \\ \text { doi:10.5539/jsd.v5n4p180 } & \text { URL: http://dx.doi.org/10.5539/jsd.v5n4p180 }\end{array}$

This research is supported by the UNESCO Regional Bureau for Science for Latin America and the Caribbean

\begin{abstract}
UNESCO-MAB biosphere reserves are composed of 580 sites distributed in 112 countries. The ecosystems comprising these sites are of global importance because of their biodiversity and endemism levels as well as because of their ecosystem goods and services provided. Biosphere reserves are learning sites for sustainable development. However many of them are threatened because of climate change, land use changes and environmental pollution which cause the degradation of natural resources. In order to mitigate those threats we argue that private and public policies as well as the perception of the value of natural resources by the population should be improved. The objective of the present article is to analyse the application and impacts of economic tools as the payment of ecosystem services in the management of the Serra do Espinhaço Biosphere Reserve.
\end{abstract}


This area was declared biosphere reserve in June 2005, it has 3076457.8 ha, which includes 53 municipalities in the state of Minas Gerais (Brazil) with a total population of 3442906 inhabitants. Economic tools have been used to revert or compensate the impacts of a large mining exploitation area located in the transition zone of this site. The ecological ICMS (Merchandise and Service Circulation Tax) that provides the municipalities with access to funding resources according to environmental criteria is analysed. Mining is the most important economic activity in the area which is a major user of land and water resources in the region. They compensate the municipalities financially for the extraction of natural resources. Both economic tools, the ecological ICMS and mining royalties, are here proposed as elements to be used to improve the social dialogue process. The decisions related to the financial resources should be considered based on the social dialogue as well as on the scientific and monitoring data. In addition, reinforce the positive effects of the participation of stakeholders.

Keywords: Biosphere reserve, Mining, Economic tools, Biodiversity, Ecosystem services

\section{Introduction}

Biosphere reserves of the UNESCO the Man and Biosphere Programme (MAB) are learning sites for sustainable development. Their ecological characteristics and economic activities are manifested in the territory according to a system of zonation including 3 zones: core zones, buffer and transition areas (UNESCO, 1995; 2008). The core and buffer zones harbour the most biodiversity, ecosystem services and landscapes, while in the transition zones public policies of sustainable development are undertaken in the site. The notion of sustainable development in biosphere reserves has evolved to a model where biodiversity conservation and development are interdependent and applicable to the functioning of all three zones (UNESCO, 2002); biodiversity conservation in core zones should be considered in relationship to social and economic development in the entire area as they provide the important services to benefit its inhabitants; similarly, the development in buffer and transition zones must be related to environmental improvements in all the biosphere reserve (Ishwaran et al., 2008). Education, research and monitoring play an important role in the functioning of biosphere reserves because they enable the learning on conservation and development policies and practices in the field. Amongst the main environmental management policies for biodiversity conservation are environmental impact assessment (EIA), the creation of protected areas and economic tools such as payment for ecosystem services. The main advantage of these instruments is to allow for the integration of ecological, social and economic aspects of environmental management. The present study on the Serra do Espinhaço Biosphere Reserve aims at analyzing the impact of economic environmental management tools over the past 10 years on local municipalities that comprise the reserve. The ecological ICMS (Merchandise and Service Circulation Tax) is compared to mining royalties and its application to conserve biodiversity and ecosystem services through the creation of protected areas is analysed.

\subsection{Ecosystem Services}

Ecosystem services or environmental services are defined as the benefits that human beings obtain from ecosystems (Millennium Ecosystem Assessment, 2005). According to the Millennium Ecosystem Assessment, environmental services can be divided into four types: provisioning (food, water, fibber), supporting (primary production, nutrient cycle, soil formation), regulation (climate regulation, water quality) and cultural services (tourism, recreation, spirituality). Although some of the benefits as, for example, food, water or timber, are easier to be recognize by human communities, others such as climate control or nutrient cycle have only been recognized recently.

Raw materials converted into economic products, regulation services (for example: water and climate), cultural services and information (for example: recreation and genetic diversity) constitute irreplaceable and essential benefits for all living beings. Otherwise, these ecosystem services are not readily recognized by human communities as are the other services, even in spite of the increasing natural disasters in the recent decades.

Economic interventions provide instruments to regulate the use of ecosystem goods and services. These interventions could be presented as the follow: elimination of subsidies that promote excessive use of ecosystem services (and transfer of these subsidies to payments for non-marketed ecosystem services); use of taxes for activities with external costs; the creation of markets as, for example, the carbon market; the payment for ecosystem services of compensation for unavoidable harm; mechanisms to enable consumer preferences to be expressed, for example, through certification schemes for sustainable uses of natural resources (Millennium Ecosystem Assessment, 2005).

Over the past ten years, many countries have adopted economic tools to pay for environmental services or for environmental compensation and have also introduced certification systems for sustainable production. Some governments have started to price carbon, either through taxation or through emissions trading by means of 
addressing externalities. According to the United Nations Secretary-General's High-level Panel on Global Sustainability (2012) this should not penalize the poor, which are already the most affected group by environmental degradation.

There are several examples of mechanisms for payments or compensation for ecosystem services in the biosphere reserves. Examples in Latin America and the Caribbean are showed in a compilation of good practices of climate change mitigation and adaptation carried out by the German Commission for UNESCO (2011). Aguay Paz Biosphere Reserve in Costa Rica has been declared carbon neutral. Private companies are financing projects for mitigation of climate change through forestry or agriculture, or rehabilitation of high-carbon ecosystems. In Colombia, Sierra Nevada de Santa Martha, participatory projects implemented by indigenous people are supported by national funds for the restoration of ecosystem and sustainable agriculture. In Cuba, projects financed by GEF (Global Environmental Facility) are currently implemented to improve agriculture and to mitigate climate change by using traditional practices and adapted local varieties (German Commission for UNESCO, 2011). Sierra Gorda Biosphere Reserve in Mexico has been financed by GEF (Global Environmental Facility) and co-financing came from a wide range of project partners (Persic et al., 2008). This biosphere reserve developed a voluntary market for carbon and other environmental offsets. Other case studies in Latin America and worldwide present schemes for payment of ecosystem services in biosphere reserves (see Persic et al., 2008; Araya \& Clüsener, 2010).

In Brazil, legislation provides for the concession of financial incentives to landowners and tax transfers based on environmental criteria for municipalities within the boundaries of the in biosphere reserves. A Brazilian national programme "Bolsa Verde" distributes funds to families living in extreme poverty who promote environmental conservation in the areas where they live and work. At Serra do Espinhaço, in Southeastern Brazilian region there are two main taxation mechanisms currently used: the ecological ICMS (Merchandise and Service Circulation Tax) that provides the municipalities with access to funding resources according to environmental criteria and mining royalties that compensate the municipalities financially for the environmental negative impacts.

\section{Serra do Espinhaço}

Located in the north-south axis of the States of Minas Gerais and Bahía, the Serra do Espinhaço harbours three highly important Brazilian biomes for the conservation of biodiversity: Caatinga, Cerrado and Mata Atlantica. The last two biomes are included in the list of the only two Brazilian biome hotspots (Myers et al., 2000). The Serra do Espinhaço is comprised by a mosaic of vegetations, where the most expressive is the "campos rupestres" or rupestrian fields.

In 1693 the region was the scenario of the first discovery of Brazilian mineral richness by the Portuguese, who named the area Minas Gerais. From the end of the seventeenth century until the nineteenth century, Serra do Espinhaço was a obligatory passage, first from São Paulo along the "Camino Velho" (Old Road) and, later, from Rio de Janeiro, along the "Camino Novo" (New Road) (see Figure 1). The Historical Town of Ouro Preto, the Santuario Bom Jesus in Congonhas and the Vila de Diamantina Historical Centre are cities with outstanding baroque art and architecture in the Serra do Espinhaco Biosphere Reserve declared as Word Heritage cultural sites.

Nowadays the main activity in this biosphere reserve is mining, it is one of the largest mining exploitations in the world and the most important one in Brazil.

Other activities carried out in the territory are open-range livestock breeding, subsistence or family agriculture and plant extraction. Agriculture, craftwork, tourism and biodiversity prospection in the buffer zones have benefited from the creation of the Serra do Espinhaço Biosphere Reserve.

The implementation of a huge investment project involved four big possibilities for promoting the local economy, through the generation of jobs, income, domestic trade and tax system expansion. According to the Brazilian Institute of Mining (IBRAM, 2007), mining has led to a significant change in the profile of local employment in the region because it involves a specialized work force at almost all levels of qualification.

In this respect, the intention has been to plan both existing and prospective mining projects in the biosphere reserve, mainly of a private nature, contributing to the maintenance of ecosystem goods and services and traditional activities of the communities.

\section{Methodology}

Two economic instruments were chosen to mainstream the research, which are directly related to the environmental management in the biosphere reserve and exert strong influence on the municipalities. The first 
instrument mobilizes finances originated in the existence of conservation units characterized as Payment for Environmental Services (Ecological ICMS - Merchandise and Service Circulation Tax). The second instrument comes from the exploitation of natural resources enforcing the obligation to pay an environmental compensation (CFEM - Compensation for the Exploitation of Mineral Resources). Both economic modalities are introduced in order to display the financial amount generated and distributed within a territory with a historical extractive profile. With an exploitation of 27 types of minerals, its reserves are located in 30 studied mining municipalities.

This research was conducted with the data about conservation units reported by the Institute of Forests of Minas Gerais (IEF/MG) used to prepare the Ecological ICMS index, regarded as the criterion for distribution of the ICMS transfer, as provided by the state law (Note 1). The ecological ICMS is divided into actions addressed to improvement of waste and sewage treatment systems, and actions intended to protection of the conservation units; $0.5 \%$ of the municipalities' ICMS is allocated to each of such actions. Core areas of Serra do Espinhaço Biosphere Reserve were used to assess the impact of the distribution of resources of the ecological ICMS on municipalities. The National System of Conservation Units (SNUC - Law No. 9.985) establish as the main objective of the conservation units of integral protection the preservation of nature, therefore, only the indirect use of their natural resources is allowed.

In order to calculate the evolution of the resources allocated to the Ecological ICMS and the conservation unit sub-criterion the data was reported by the João Pinheiro Foundation, government body of Minas Gerais in charge to disclose the transfer amounts of such resources. To calculate the actual values, the General Price Index Domestic Availability (Índice Geral de Preços - Disponibilidade Interna, IGP-DI) (Note 2) was applied to the nominal values to facilitate the comparison of the time series, by excluding inflation.

The comparative study between the two absolute values of both instruments as well as the territorial dimension, both of the mining activity and of the conservation efforts, are the main axes proposed to subsidize the social dialogue, integrating mining and sustainability actions in Serra do Espinhaço Biosphere Reserve.

\section{Results}

Serra do Espinhaço comprises 53 municipalities (Figure 2); of these, 29 have populations of less than 10000 inhabitants, 17 between 10000 and 50000 inhabitants; and 6 have populations of around 150000 inhabitants, while the State capital has 2258096 inhabitants (IBGE, 2010). The growth rate of the population between 2000 and 2010 was unequally in the Serra do Espinhaço Biosphere Reserve. It has been correlated to the economic development and also the human development index. The 15 municipalities that received most funds from mining royalties are among the 14 municipalities with higher population growth. Among the reasons for this higher growth rate is the municipality's economic development (Figure 2).

The HDI (Human Development Index) is higher in the state capital, Belo Horizonte (0.839) and reaches the lower value of 0.626 in Senador Modestino Gonçalvez. Most of the municipalities showing a HDI close to 0.6 correspond to the villages with negative or zero population growth. These towns do not have mineral deposits, showing that mining has represented a factor for the development in the region (Figure 2).

\subsection{Ecosystem Services Provided by the Serra Do Espinhaço Biosphere Reserve}

The highest rate of endemism Brazilian flora is found in the mountain range of Espinhaço, particularly in the Serra do Cipó. In addition to an exceptional rate of endemism in fauna, the Espinhaço mountains also represents a huge water reservoir. The mountains divide two major watersheds in the region: to the west the São Francisco Basin and to the east the Doce and Jequitinhonha rivers.

The campos rupestres are formed by a rich mosaic of plant communities that depend on the local land form, nature of the substratum and microclimate and even on the interaction with microorganisms, as recently discovered (Fernandes et al., 2011; Carvalho et al., 2012). It is an extremely fragile ecosystem with low resilience. The rupestrian vegetation which is associated to metal-rich soils in the region known as Iron Quadrilateral has ca $80 \%$ of endemic species occurring in iron-rich substrates, $10 \%$ in substrates rich in chrome, niobium, bauxite and manganese while other $10 \%$ are associated to nickel-rich substrates. More than 40 species are extremely specialized to bioaccumulate metals and they should be preserved because of their potential in site restoration (Jacobi et al., 2011), while hundreds of other ones are tolerant to heavy metals as well (GWF, unpublished data). The loss of plant species associated to metal rich areas should be considered as ecologic and genetic damages derived from surface-mining activities.

In the dry season, fire is a natural agent in the rupestrian field and many plant species are adapted to survive the periods of fire. On the other hand, recurrent fires may represent a problem yet now measured, but that could represent a major direct and indirect threats to the finely adapted species (see Barbosa et al., 2010). In the rainy 
season, plants are abundant, favouring the appearance of lots of animals which depend on nectar and pollen, like humming-birds and bees and even ungulates.

In the area of Serra do Espinhaço Biosphere Reserve, because of its edaphic, geomorphological and particular biodiversity, only small scale agriculture could be practiced. Family agriculture is thus of great importance due to its potential for plant extractivism. Restrictions naturally imposed by edaphic, and geomorphological features in Serra do Espinhaço Biosphere Reserve inhibit large scale agriculture. The singular biodiversity and endemism levels should also be considered during the agricultural expansion planning. Family agriculture is thus of great importance in the region due to its potential for plant extractivism.

The landscape is characterized by scenic beauty and environmental richness which included in 11 core areas of a total surface of 204522.14 hectares. Buffer zone has a greater quantity of conservation units: 16 PEAs (Protected Environmental Areas), one State Forest and 4 PNHR (Private Natural Heritage Reserves) (Figure 3). It includes 1879996.65 hectares and was created based on the distribution of rupestrian fields, basins, the priority areas for biodiversity conservation in Minas Gerais historic cities, occurrence of geological monuments and distribution of conservation units of sustainable use (Sistema National de Unidades de Conservação, SNUC).

\subsection{Payment for Environmental Services: Ecological ICMS}

The ecological ICMS (Merchandise and Service Circulation Tax) is a mechanism that provides the municipalities with access to funding resources according to environmental criteria through a State law for the distribution of the share that the municipalities have the right to receive as a constitutional transfer.

In 2009, the municipalities had a total of 72 conservation units (CU) registered in the Institute of Forests of Minas Gerais (IEF/MG) at a provincial level and 14 municipal CU in Minas Gerais State (Brazil). The Serra do Espinhaço Biosphere Reserve covers an area of 3076457.8 hectares with a total of 2084518 ha (68\% of the total surface) corresponding to conservation units.

The ecological ICMS is a pioneer mechanism for tax compensation in Brazil based on the "protector-receiver" principle. Its impact has been huge in some municipalities, such as, for example, in São Gonçalo of Rio Preto, which received $3691 \%$ extra from the transfer following the implementation of this tool. In this municipality, the process contributes to the idea that the conservation unit is the main source of funds to the municipality. Figure 4 shows the distribution of Ecological ICMS transferred in 2009 among municipalities in Serra do Espinhaço Biosphere Reserve.

In the first three years of the law, the number of conservation units doubled in Minas Gerais State, although the majority of the areas created were sustainable use units, specifically EPAs (Environmental Protection Areas). The total amount of ecological ICMS transferred to municipalities in 2009 was US\$ 12903 400, representing an average of 6 dollars per hectare per year. Otherwise this value is very low and poorly distributed in relation with the territory's ecosystem services.

However Ecological ICMS is considered as a promising mechanism as it originated an increase in conservation units in the region and has improved the municipalities where it has been implemented.

\subsection{Compensation for Mining Exploitation}

The protection of the Serra do Espinhaço Biosphere Reserve's ecosystem services - rupestrian vegetation, water and culture- is now in conflict with mining, urban expansion and infrastructure projects. Presently, the increase in supply of raw materials caused by increasing consumption and population growth exerts high pressure on the Serra do Espinhaço ecosystems. The high dividends obtained from mineral exportation are a stimulus to the economy.

Compensation for the Exploitation of Mineral Resources (CFEM) is paid by all those carrying out mining activities. It is calculated on the basis of net invoicing obtained from sales of the product, that is to say, after all marketing taxes, transport and insurance expenditures have been deducted.

CFEM rates for the exploitation of mineral resources are $0.2 \%$ for precious stones, coloured and carbonated stones and precious metals; $1 \%$ for gold; $2 \%$ for iron; $3 \%$ for aluminium, manganese, rock salt and potassium. About $12 \%$ of this percentage is retained by the Nation, $23 \%$ goes to the State and about $65 \%$ is assigned to the municipality where the mineral was extracted.

Less than half of the CFEM collected in the country from January to August 2009, amounting to about US\$ 284.35 million, went to the state of Minas Gerais (about US\$ 124.20 million), responsible for $45 \%$ of all Brazilian mineral production (National Department of Mineral Production). In Brazil the two most benefitted States are Minas Gerais with $43 \%$ of mining royalties and Pará with $33 \%$. 
In 2010, resources from compensation for mining exploitation received by the municipalities were 20 times higher than those from Ecological ICMS. These resources should be applied to promote sustainable development in the municipalities and for maintenance and restoration of ecosystem services in collaboration with the mining sector and the society (Table 1).

\section{Discussion and Conclusion}

Serra do Espinhaço is responsible for providing water to millions of Brazilians and many of its springs are threatened by deforestation, fires, silting and contamination. Moreover, the loss of biodiversity is very significant in this highly variable and fragile territory. The environmental impacts are increasingly higher on the traditional communities and they also affect the quality of life of its inhabitants.

The Madrid Action Plan for Biosphere Reserves recommends improving the financing of biosphere reserves, the payment for ecosystem services and the creation of partner agreements for forests and water (UNESCO, 2008). Another target would be the improvement of benefit-generation and quality of life of local communities.

However financial transactions and administrative modifications from enterprise actions prevent corporative leaders from creating any relationship with the populations in the areas in which their companies are located.

Resources for investments in "green" municipalities, that is to say, those municipalities providing conservation of ecosystem services through protected areas, in addition to the restoration of territories from extractive activities, should be as high as the funds from economic growth stimulating consumption. This would promote the reduction of environmental degradation and the establishment of a new form of municipal economy geared towards sustainable development by promoting the welfare to the populations.

The economic tools presented in this study should not be considered as a path to be followed, but as elements to be included in a social dialogue process. Through compensation for mining exploitation (mining royalties), or environmental criteria for ICMS to be distributed in the municipalities, it is possible to create strategies for economic development to fund maintenance of environmental services as well as to create green jobs.

Ecological ICMS is a tax which is proportional to consumption. As we seek to reduce the pressure on ecosystems, new paths are needed to guide biological diversity conservation. Sustainability requires more than a management system or laws. Public policies should promote greater effectiveness in those mechanisms for ecosystem protection and restoration.

The price per ton of mineral iron has increased considerably over the last ten years. Increased demand and the reduction of mineral reserves have created a scenario of growing ecosystem pressure. Considering that financial compensation for mining municipalities and ecological ICMS do not have a mandatory environmental aim, municipalities have to decide on the application of these resources. So far, Conservation Units and Biosphere Reserve territories are far from receiving reasonable benefits from the use of ecosystem services.

The reinforcement of these mechanisms based on sustainable practices, is feasible by taking into account collective solutions. An assessment of the actual scenario and of the evolution dynamics of renewable natural resources' exploitation activities is proposed as a perspective to this case study, in the context of the Serra do Espinhaço Biosphere Reserve. This requires a revision of existent sustainable development indicators as well as the creation of new ones that would contribute to improve a local dialogue, to improve participation of local communities and to devise cooperative plans resulting in guidelines for sustainable practices and strategies for integrated territorial management.

\section{References}

Araya, P., \& Clusener-Godt, M. (2010). Reservas de la Biosfera. Su Contribución a la Provisión de Servicios de los Ecosistemas. Experiencias Exitosas en Iberoamerica. UNESCO.

Barbosa, N. P. U., Fernandes, G. W., Carneiro, M. A. A., \& Júnior, L. A. C. (2010). Distribution of non-native invasive species and soil properties in proximity to paved roads and unpaved roads in a quartizitic mountains grassland of southeastern Brazil (rupestrian fields), Biol. Invasions, 12, 3745-3755. http://dx.doi.org/10.1007/s10530-010-9767-y

Camargos, R. M. F., \& Lanna, M. T. (1996). Cadastro das áreas naturais protegidas em Minas Gerais. GNOMOS, 4 (2), 55-67. [Online] Available: http://www.igc.ufmg.br/geonomos/indice42.htm (March 2, 2012)

Carvalho, F., de Souza, F. A., Carrenho, R., Moreira, F: M: S:, Jesus, E. D., \& Fernandes, G. W. (2012). The mosaico $\mathrm{f}$ habitats in the high-altitude Brazilian rupestrian fields is a hotspot fro arbuscular mycorrizal fungi, Applied Soil Ecology, 52, 9-19. http://dx.doi.org/10.1016/j.apsoil.2011.10.001 
Da Veiga Neto, F. C. (2000). Análise de Incentivos Econômicos nas Políticas Públicas para o Meio Ambiente O caso do ICMS ecológico em Minas Gerais. Dissertação apresentada no Curso de Pós Graduação em Desenvolvimento, Agricultura y Sociedade, CPAD, do Instituto de Ciências Humanas e Sociais da Universidade Federal Rural do Rio de Janeiro.

Espinhaço Range Biosphere Reserve. (2005). Nomination Proposal Phase I. pp. 189.

Fernandes, G. W., Oki, Yumi, sanchez-Azofeifa, A., Faccion, G., \& Amaro-Arruda, H. C. (2011). Hail impact on leaves and endophytes of the endemic threatened. Coccoloba cereifera (Polygonaceae), Plant Ecology, 212 (10), 1687-1697. http://dx.doi.org/10.1007/s11258-011-9941-z

German Commission for UNESCO. (2011). For Life for Future. Biosphere Reserves and Climate Change. A Collection of Good Practice Case Studies. Bonn.

IBRAM. (2007). Relatório do Instituto Brasileiro de Mineração.

ICSU-UNESCO-UNU. (2008). Ecosystem Change and Human Well Being: Research and Monitoring Priorities. Based on the Millennium Ecosystem Assessment.

Ishwaran, N., Persic, A., \& Tri, N. (2008). Concept and practice: the case of UNESCO biosphere reserves, Int. J. Environmental and Sustainable Development, 7 (2), 118-131. http://dx.doi.org/10.1504/IJESD.2008.018358

Jacobi, C. M., do Carmo, F. F., \& de Campos, I. C. (2011). Soaring extinction threats to endemic plants in Brazilian metal-rich regions, Ambio, 40 (5), 540-543. http://dx.doi.org/10.1007/s13280-011-0151-7

Loureiro, W., \& Martinez, A. (2004). ICMS Ecológico como Instrumento de Apoio às RPPN no Paraná. [Online] Available: http://www.rppnbrasil.org.br/icms (December 10, 2007)

Loureiro, W. (1998). Incentivos Econômicos para Conservação da Biodiversidade no Brasil: ICMS Ecológico. Curitiba.

Meyers, N., Mittermeier, R. A, Mettermeier, C. G. Fonseca, G. A. B., \& Kent, J. (2000). Biodiversity hotspots for conservation priorities, Nature, 403, 853-858. http://dx.doi.org/10.1038/35002501

Millennium Ecosystem Assessment. (2005). Ecosystems and Human Well-Being: Synthesis. Washington, DC: Island Press.

Millennium Ecosystem Assessment. (2005). Ecosystems and human Well-Being: Current State and Trends. Washington, DC: Island Press.

Persic, A., Arico, S., Calvo, G., \& Ishwaran, N. (2008). Ecosystems and human well-being: UNESCO Biosphere reserves as learning laboratories for sustainable development In: Secretariat of Convention on Biological Diversity. Protected Areas in Today's World: Their Values and Benefits for the Welfare of the Planet. Montreal. Technical Series No. 36, pp. 87-94.

The Nature Conservancy (TNC) - A Genuine Brazilian Incentive for Conservation - Ecological ICMS. [Online] Available: http://www.icmsecologico.org.br/index.php?option=com_content\&view=article\&id=58\&Itemid=68

(February 1, 2012)

UNESCO. (1995). Biosphere Reserves. The Seville Strategy and the Statutory Framework of the World Network, UNESCO, Paris, France, pp.18.

UNESCO. (2002). Biosphere Reserves: Special places for people and nature. UNESCO. Paris.

UNESCO. (2008). Madrid Action Plan for the Biosphere Reserves (2008-2013). Paris

United Nations Secretary-General's High-level Panel on Global Sustainability. (2012). Resilient People, Resilient Planet: A future worth choosing. New York: United States. [Online] Available: http://www.un.org/gsp/. (February 1, 2012)

\section{Notes}

Note 1. Law $n^{\circ} 13.803$ of December 27, 2000.

Note 2. The IGP-DI for the years 2008; 2007; 2006; 2005; 2004; 2003; 2002; 2001; 2000; 1999; 1998 and 1997 were, respectively, 1.0179137327024; $1.13224363325704 ; 1.18978082286859 ; \quad 1.21030407194362$; $1.28250490579589 ; \quad 1.40308305913552 ; \quad 1.7229559463965 ; \quad 1.95562731935325 ; \quad 2.15825271007462$; 
Table 1. CFEM (Compensation for the Exploitation of Mineral Resources): Tax collection in 2010 by the municipalities

\begin{tabular}{|c|c|c|}
\hline MUNICIPALITIES & MINERALS & $\begin{array}{l}\text { ROYALTIES } \\
\text { in } 2010 \\
\text { (US dollars) }\end{array}$ \\
\hline Nova Lima & Bauxite clay, refractory clay, iron, iron mineral, gold, serpentinite & 46245260 \\
\hline Itabira & Sand, quartoze sand, clay, emerald, iron, gemstone, gneiss, gold mineral & 42407132 \\
\hline Mariana & Bauxite, soapstone, iron, iron mineral, quartzite, saponite & 37185543 \\
\hline Congonhas & Sand, iron, granite, iron mineral & 21056016 \\
\hline Brumadinho & Mineral water, sand, iron, iron mineral & 19232455 \\
\hline Itabirito & $\begin{array}{l}\text { Mineral water, sand, clay, kaolinite, iron, phyllite, gneiss, manganese, iron mineral, } \\
\text { gold mineral, silver mineral }\end{array}$ & 18632151 \\
\hline Ouro Preto & Limestone, dolomite, iron, gneiss, ochre, imperial topaz & 13199675 \\
\hline Barão de Cocais & Dolomite, iron gneiss, gold mineral & 10528860 \\
\hline Sabará & $\begin{array}{c}\text { Mineral water, sand, iron, gneiss, iron mineral, gold mineral, silver mineral, gold, } \\
\text { pyrite }\end{array}$ & 3972595 \\
\hline Santa Bárbara & Bauxite, iron, iron mineral, gold mineral, ochre, gold, serpentinite & 4626923 \\
\hline Catas Altas & Iron, serpentinite & 3431238 \\
\hline Sarzedo & Iron mineral & 386069 \\
\hline Rio Acima & Clay, ochre & 264777 \\
\hline Total & & 221168694 \\
\hline
\end{tabular}

Source: National Department of Mineral Production 


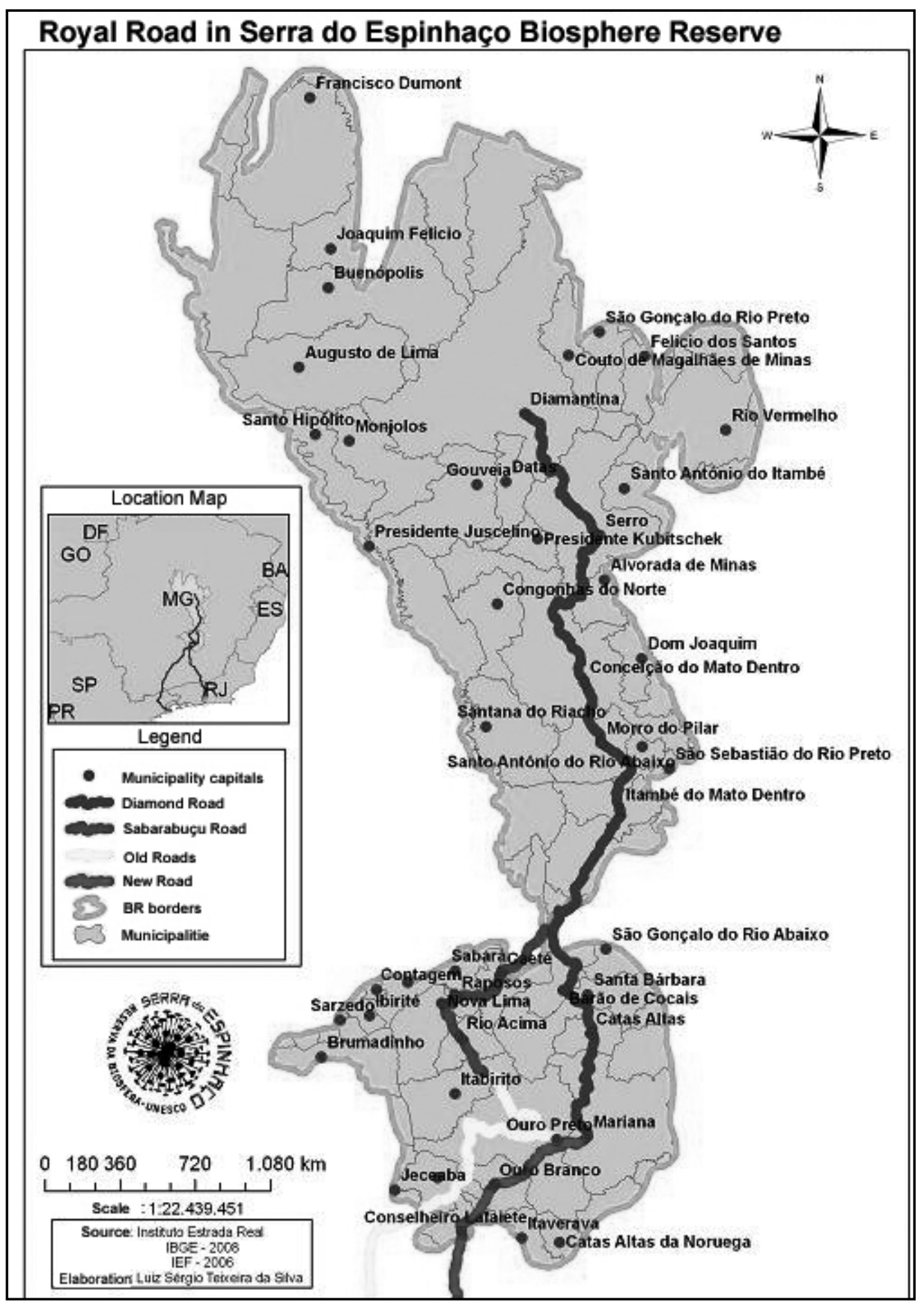

Figure 1. "Estrada Real” (Royal Road) 


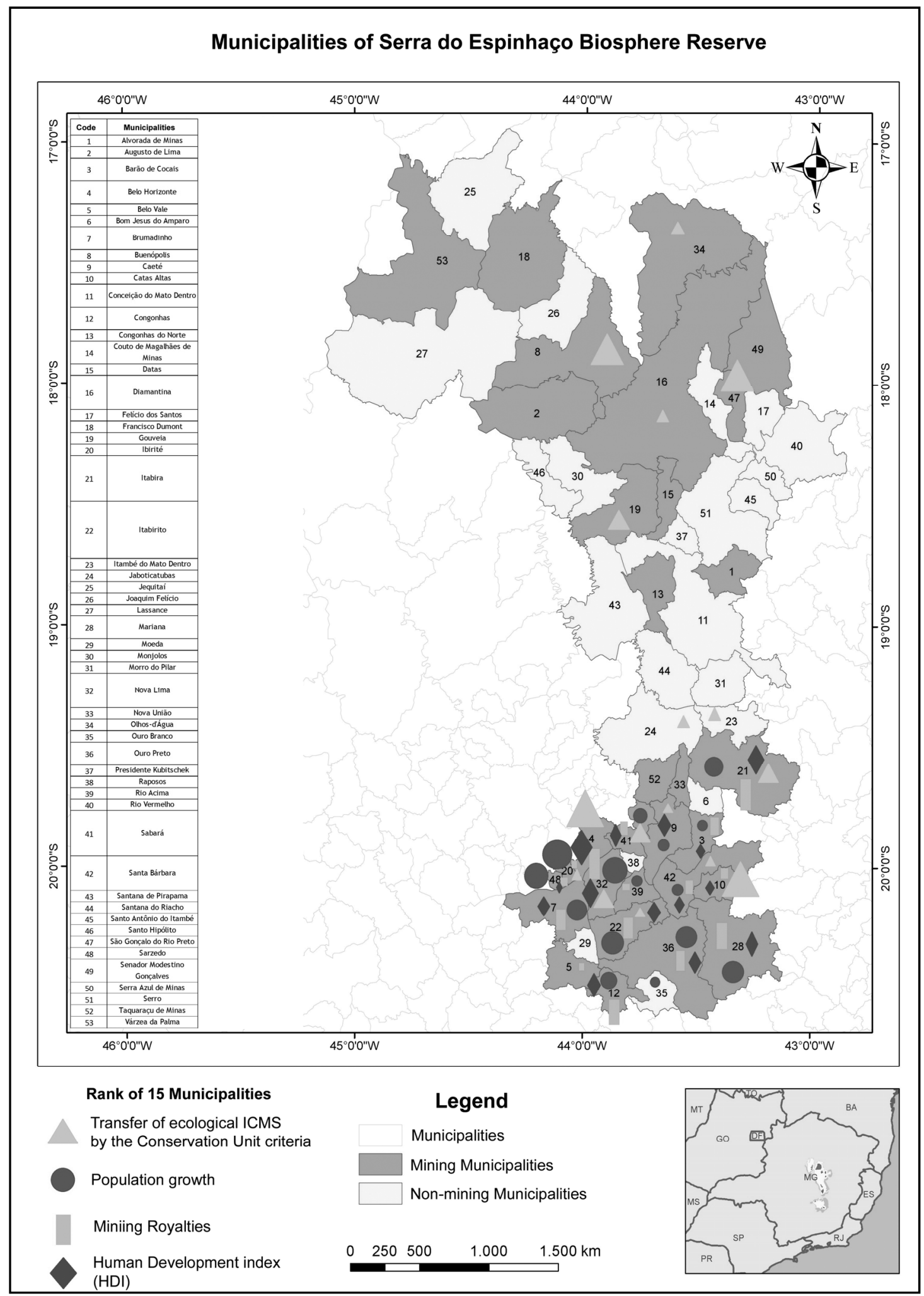

Figure 2. Municipalities of the Serra do Espinhaço Biosphere Reserve according to population growth, HDI, royalties and Ecological ICMS 


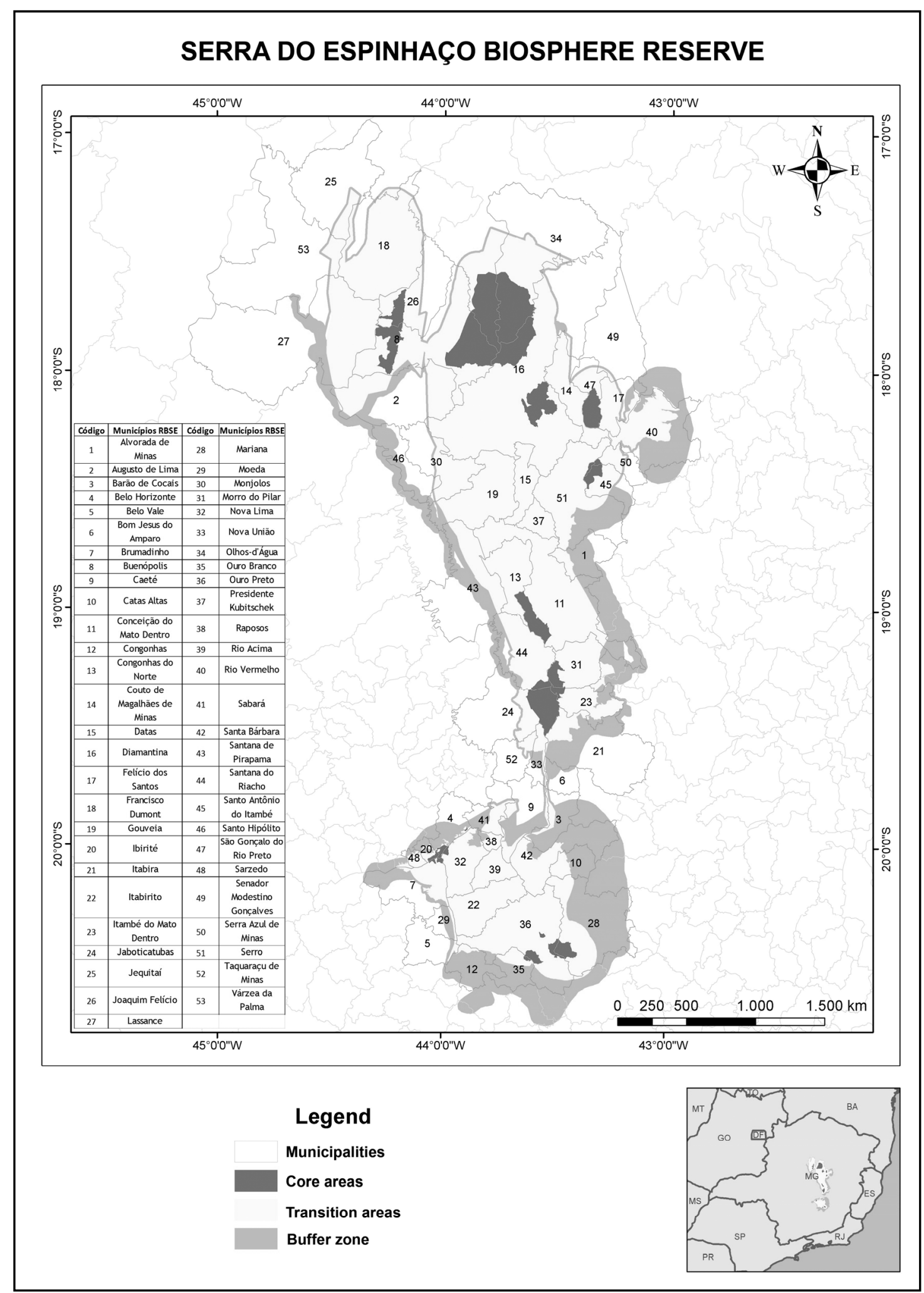

Figure 3. Zonation of the serra do espinhaço biosphere reserve 


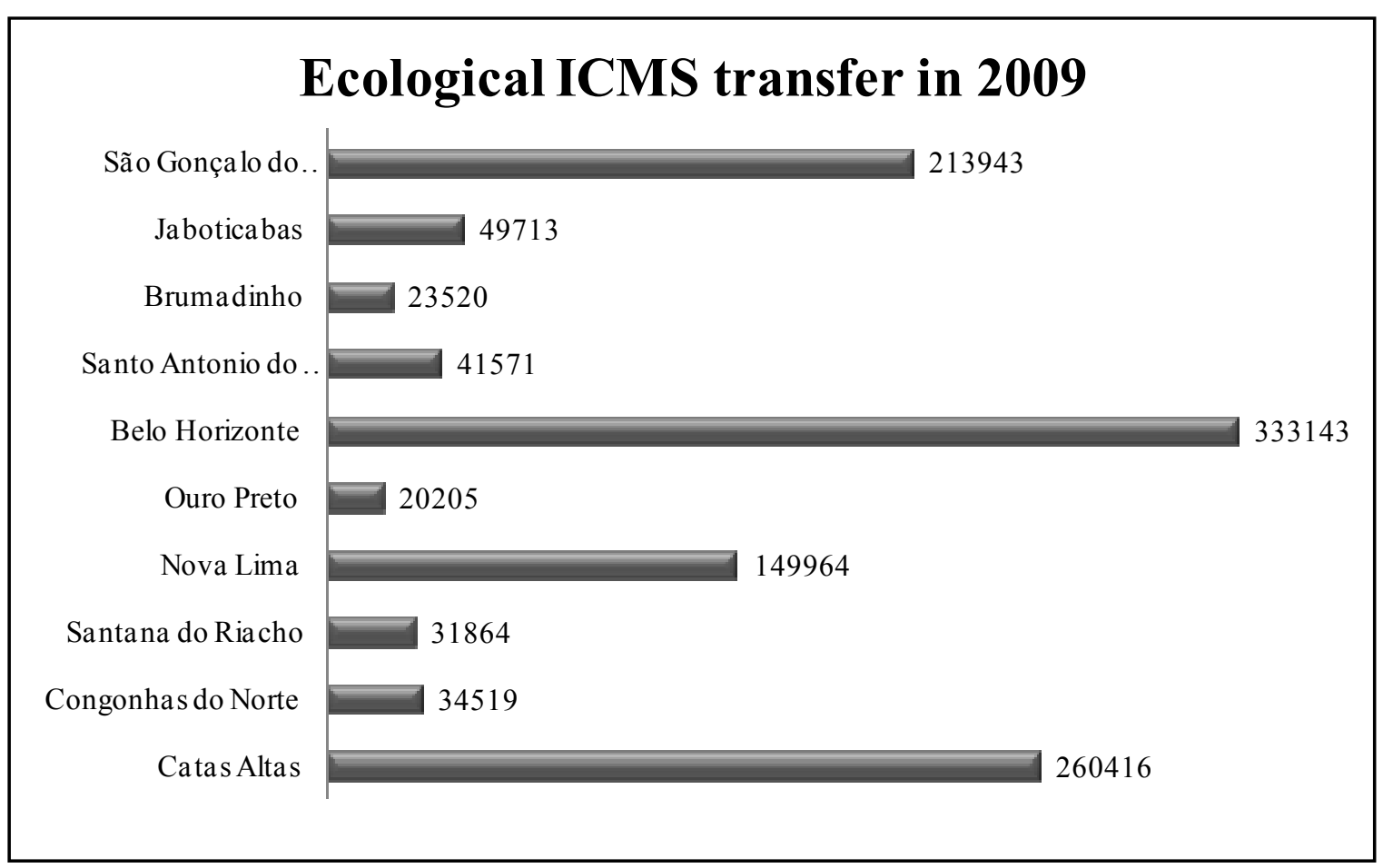

Figure 4. Ecological ICMS transfer to municipalities (in US dollars) 